\title{
Towards the development of a global communicative competence: the integration of oral and written skills in teaching and learning a foreign language
}

\author{
Eduardo Constanzo \\ The Australian National University, \\ Canberra, Australia
}

Received: 7 June 2008 / Accepted: 1 December 2008

ISSN: 1697-7467

\begin{abstract}
This article discusses the didactic perspectives that show dialogue is an essential basis for the teaching of writing. The integration of speaking and writing skills is grounded on the sociocultural theoretical framework, which considers that working in pairs stimulates the zone of proximal development (ZPD), as well as showing that inner speech is a key element in the planning process of writing. Based on these premises, we present a final theoretical proposal, which constitutes the foundation of the concept of interactive writing classroom in a foreign language.

Key words: orality and writing, didactics in a foreign language, integration of skills, oral language, writing in a foreign language.

Hacia el desarrollo de una competencia comunicativa global: la integración de las destrezas orales y escritas en la enseñanza-aprendizaje de una lengua extranjera

RESUMEN: Este artículo revisa las perspectivas didácticas que sostienen que la interacción oral es una base esencial para la enseñanza de la escritura. La integración de ambas habilidades se presenta a la luz del marco teórico sociocultural, que considera que el trabajo en parejas permite estimular la zona de desarrollo próximo y el lenguaje interior se concibe como un elemento clave del proceso de planificación de la escritura. Una propuesta final, que considera la lengua oral y escrita como base de las actividades de instrucción, se constituye en el fundamento del concepto de aula interactiva de escritura en LE.

Palabras clave: oralidad y escritura, didáctica de idiomas extranjeros, integración de destrezas, lengua oral, escritura en lengua extranjera.
\end{abstract}

\section{INTRODUCTION}

In recent years, researchers in the area of language teaching ${ }^{1}$ have made significant contributions to improve our understanding of the cognitive, linguistic and social processes involved in learning a language. Challenging new propositions have stimulated empirical

1. Throughout this work we will use the expressions foreign language and second language (L2) as equivalent. This is due to the fact that many of the didactic and theoretical point of views that we gather here are applicable as strategies for teaching and learning in both of them. 
studies, some of which have led to the reformulation and improvement of traditional theories. What had once been dealt with in isolation is now seen from an integrative perspective; what was taught as a separate skill is now taught from a holistic point of view. These processes have afforded us an understanding of the importance of integrating skills in teaching and learning one or more languages, a fact that becomes more relevant when we pursue the development of writing skills in the classroom.

The traditional view suggests that educators, when confronted with the task of teaching students to write, can regard writing as an activity either different from the spoken discourse or similar to it. The first position conjures the perception of the act of writing as antisocial and the spoken discourse as a social activity. The second position is premised on the metaphor that writing, like the spoken word, is a conversational act (Vygotsky, 1996 [1934]; Weissberg, 2006). Researchers who subscribe to the latter view often highlight the ways in which oral discourse supports writing, with a particular focus in areas where conversation reinforces the learning process (Sterling, 1996).

In this paper we review the didactical perspective associated with the latter position, that is, a view that integrates the written with the oral skills to produce written texts in the classroom. Our goal is not to allude to a voluminous number of investigations, but to consider those inputs that contribute specifically to illustrate aspects important to the teaching of writing that present (and future) research and practice should consider in order to pursue and implement in the classroom.

\section{RELATIONS BETWEEN ORALITY AND WRITING IN THE DEVELOPMENT OF THE MOTHER TONGUE}

The teaching of writing is usually introduced from the age of 5, when children commence their formal education, although some nascent forms of true writing often commence to appear before school begins (Bisexx, 1980). But even though writing can take shape at a very early age, oral language has reached a level of development far beyond that of the written language. This means that although writing skills develop later in the learning curve of language (Vygotsky, 1996 [1934]), or require more time than any other linguistic skill to reach full development, they have the potential to be affected by the spoken language. Understanding how these two language skills correlate with each other can reveal the level of progress that is able to be achieved in writing. It also shows in what manner and to what degree writing can be influenced by the spoken language (Shanahan, 2006).

From these propositions, it seems feasible for oral language to be a valuable foundation for the development of writing: novice writers can rely on their knowledge of various aspects of oral language such as lexicon, morphology, syntactic structures, the structure of the discourse and pragmatic elements, to gradually develop their written competence. Confidence in these aspects can, from a theoretical point of view, make the development of writing more efficient and allow faster progress on the part of students, particularly those with a better developed spoken language skills (Shanahan, 2006).

The studies that have addressed the connection between oral and written competences have explored this topic from different analytical perspectives. Therefore, it is possible to find 
well established streams that focus their studies on the early stages of the process of learning the written language that question the traditional maturational hypotheses. These argue that since mastering reading and writing requires the presence of a certain level of meta-linguistic consciousness in the phonological area, the higher the volume and grasp of the spoken language the child possesses, the earlier and easier his initiation into writing and reading activities will be ${ }^{2}$ (Romero, Fdez de Haro and Núñez, 2008). At subsequent stages in the learning process, one of these theories focuses on studying the mother tongue in a formal instructional context with a strong emphasis on learning basic structures during primary and secondary schooling.

It has been demonstrated that effective writing depends on the verbal working memory ${ }^{3}$ (McCutchen, 1996). If this aspect of the verbal competence has not developed, then the students find it difficult to produce well structured compositions. Regarding discursive cohesion, that is, the way in which writers and speakers influence the coherence of the ideas they communicate, Pappas (1985) showed that the degree of cohesive harmony in students from first grade of high school is higher in oral stories but lower in written ones. Other studies have shown how the cohesion that develops early in the spoken language tends to be reflected later in children's writings (Cox, Shanahan \& Sulzby, 1990).

Shanahan (2006) maintains that oral and written language are closely connected from a general viewpoint, thus children that have well-developed spoken language skills perform better when writing. In particular, writing seems to make use of oral language in the development of cohesion. However, it has been discovered that writing also has an impact on oral language, at least in the forms that develop later in the process such as the morphemes, where writing may cause certain characteristics of the language to become more noticeable to the novice.

And so, morphology has been another area that has received attention in relation to the connection between speech and writing. Carlisle (1996), in a study that examined the use of morphemes in oral and written composition, found that mistakes of oral language explained many of the morphological errors that occurred in writing. Another research (Green et al., 2003) demonstrated the closeness between the oral and written language in relation to the morphological development during the first years of schooling. The study focused on the development of morphological markers in the writing of narrative texts for children of third and fourth grade. In summary, the study concluded that the grasp of the morpho-syntactical structures in writing reflects that of the oral discourse. The morphology of the flexive forms is mastered at 9 years of age, while the skills in the use of derivative forms continue to develop beyond that age.

Similar results were yielded by a study that worked with five adult participants who tried to test new morphological and syntactic structures in their writing, but not in their oral language (Weissberg, 2000). The information was collected through a variety of written and

2. Teberosky (1991); Ferreiro and Teberosky (1993) and Tolchinsky, L. (1993).

3 . There is a consensus that the information is stored in the working memory during the writing process. The problem is that there are more resources devoted to processing functions, but few resources for storing information. Given these limitations, the implications for complex processes such as the writing is clear: to compose a text, expert writers coordinate the planning in their working memory (content plan, audience, etc.) and the goals of the final product (grammar, achievement of the plan), all of this while the process of generating language retrieves words in order to express the contents and organize them into an appropriate text (McCutchen, 1996: 300-301). 
oral activities over the length of one semester. The results showed that three of the participants expressed a preference for writing, rather than the oral discourse in the morpho-syntactical development. The remaining two exhibited a more balanced approach between speech and writing in the development of the language. At the same time, the oral syntax of the older participants (33 and 35 years) remained comparatively crude and showed limited progress. For the group as a whole, the grammatical precision in the written expression doubled, compared with that of the oral discourse. Weissberg (2000) claims that the findings of this study achieve a better understanding of how the change occurs between the oral and the written forms in the process of learning a language. Furthermore, lengthy, more detailed studies need to be conducted with a larger number and a broader diversity of subjects.

Shanahan (2006) indicates that the lack of attention to the connection between the oral and written expression is probably due to deficiencies in the treatment of the formal oral language in school, combined with the historical neglect of coaching on writing. This author adds that there are modest amounts of time devoted to instruction in oral and written skills, so it would appear that there is little reason to deal with these issues. Similarly, Shanahan observes that although a great deal of attention is dedicated to the oral language during early childhood or pre-basic education, the correlation between language development at an early age and the late development of the writing may not be obvious. On the other hand, some aspects of writing (for example, certain syntactic structures) could be developed faster through the teaching of oral composition, although it would be unwise to neglect the role that writing can play in the growth of these oral forms. He concludes that to establish a level of certainty based on solid foundations, it would be necessary to promote more research in these areas.

Although there are enough studies about the oral-written language relationship that suggest the potential value of this connection to understand and improve literacy in the first language, there have not been any comprehensive programs that would provide a definitive picture of the role of oral language in the writing process, or of how the instruction of spoken language could improve writing in a practical way in the context of a classroom. However, the studies that examine the relationship between language and writing in the mother tongue have shown a clear and consistent connection between verbal intelligence and writing, and have provided sufficient evidence to show that both forms of language use a similar set of skills, including working memory, linguistic cohesion and morphological knowledge.

\section{ORALITY AND WRITING IN THE LEARNING OF FOREIGN AND SECOND LANGUAGES}

The studies on writing in foreign languages have been classified by Cumming (2001) in three main areas of research: (a) studies conducted on the basis of the quality of the texts for learners, (b) works that analyse the processes of composition of texts for learners, and (c) studies that consider the sociocultural context in which learning to write occurs. Weissberg (2005) refers explicitly to the latter group, stating that there exists a considerable proportion of authors who study writing in a second language from a sociocultural perspective which he calls cross-modality research ${ }^{4}$.

4. Weissberg (2005: 94) defines the strategy of cross-modality as any research study about the use of language, whih investigates a point where the written and oral speech intersect and interconnect. 
Such an approach, although concerned mostly with writing, takes a comprehensive and rigorous look at the spoken language, as it is perceived as the instrument that establishes the social context for writing. The academic further adds that the intersection of writing and oral discourse is not only a clear and definite category in the investigation of writing on L2, but also a productive category, as it is an avenue of investigation that has much to say about the nature of writing in a second language ${ }^{5}$. In summary, watching these areas closely where writing and oral discourse in L2 intersect, we can get an appreciation of the direction to follow in the research field: how to formulate questions, how to choose methods, how to interpret information and how to correlate classroom work with composition theory.

As consequence, teachers should take advantage of the oral endeavours of the work processes to promote the development of appropriate oral skills. We also need to establish positive values and attitudes with regard to communication in general and, of course, to introduce an element of meta-cognitive reflection, of talking aloud in the composition of written texts, particularly in the planning stages.

\section{From talk to Write: the sociocultural explanation}

For the sociocultural theorists the oral discourse is the key to the development of cognitive and literacy skills. (Lee \& Smagorinsky, 2000). This connection was already explored in the academic workings of the Russian psychologist Lev Vygotsky ${ }^{6}$.

Vygotsky (1996 [1934]) conducted some experiments in which he observed the behaviour of children when subjected to a variety of tasks requiring a high level of cognitive pressure. Based on these studies, he concluded that children internalise their social discourse as a form of inner speech, a silent and abbreviated form of oral language that they use as a cognitive tool for solving problems. Vygotsky (1996 [1934]) established as a fact that the more complex cognitive functions, which include writing, develop from the social interaction that becomes transformed into inner speech, which is the final stage in the development of activity forms of the human mind. The psychological function of speech does not emerge suddenly from the social discourse, it goes, rather, through an egocentric phase in which «its formal appearance is social but its function is increasingly psychological» (Lantolf and Thorne, 2000: 72). Thus, although the egocentric speech has the appearance of social, from the point of view of the form, it has a psychological slant.

Luria (1968) (cit. by Lee and Smagorinsky, 2000) also made explicit the connection between oral speech and writing. He stated that inner speech is the basis of writing and that novice writers use it to produce a type of written speech. According to this view, the writing that emerges is simply inner speech externalised. The expert writers become accustomed to using internal discourse so the compositions they produce are so supported during the planning stages, creating an internal dialogue that helps to write them.

Several authors have used the theoretical framework of Vygotsky to study the development of writing in L2. Some have used a technique called think-aloud protocols as their methodology,

5. In this regard, Weissberg (2005: 94) refers to how people write, what subjects say about writing when they are practicing or after they do, how it is taught and how it is learned.

6. Vid. Lantof \& Thorne, 2000; Wertsch, 1991. 
in which they ask experimental subjects to talk out loud about their writings and its process, and all the while they are performing a task of composition.

As a paradigm of such process, McCutchen (1996: 301) puts forward the example of the protocol of an expert on wine that prepares his weekly column for a newspaper. At the beginning he clearly establishes his goal of reaching readers who are not necessarily experts in the field. At a later stage of drafting, the expert interrupts his writing and muses: «Now I should say 'esters and aldehydes', but if I did that, then I'd have to explain about esters and aldehydes... Why not just talk about smells and flavours?». In this case an external element influences the decision of the vocabulary chosen by the writer: he changes the focus from a chemical vocabulary to one based on perceptions, thinking of his audience. For the novice writers (children), the same process can be appreciated when they reflect or voice a few words before writing them down or during the writing process. This sense of audience is a characteristic that, according to Herrera (2005), is a crucial element in differentiating the competent students from non-competent students.

Some researchers have suggested that think-aloud protocols are an external manifestation of the inner speech of the writers of L2, a type of oral window open to the writer's process of composition (Pavlenko \& Lantolf, 2000; Prior, 2001; Woodall, 2002). Following this line of thought, Swain \& Lapkin (1998) analysed the work of pairs of students studying French. The study provides a theoretical foundation for the appreciation of dialogue not only as a means of communication but also as a cognitive tool. The information that supports this proposition comes from the analysis of the dialogue of two students of French whose task is to relate a story and then write it. As they progress with the activity, linguistic problems begin to emerge. To solve them, students use, in part, their L1 and L2 as an instrument of communication, but also, the L1 as a tool to assist in learning the L2. The conversation provides evidence of the dual use of the language as a representation of a mental process and as an opportunity to learn a L2.

Vygotsky's ideas have played a key role in encouraging writing teachers and theorists of the composition to focus on collaborative learning as a way of promoting the connection between talking, thinking and writing in students (Lee \& Smagorinsky, 2000). When the students work in pairs on a writing project, some asymmetry in their skill levels becomes apparent. That is, a member of the pair (or group) is normally slightly more advanced in a particular skill than the other member. In such a case, the oral interaction can turn into a natural learning phenomenon that Vygotsky (1996 [1934]) called the zone of proximal development (ZPD) and that was defined as:

The distance between the level of effective development, determined by the independent resolution of a problem and the level of potential development, determined through the resolution of problems with the help of an adult or in collaboration of more capable peers (Vygotsky, 1978: 86).

To illustrate this concept, McLane (1994) presents the experience of a group of children in a writing program. At the beginning of the activity, the students talked among themselves and with their instructors about their writing. They sought help from their peers and teachers when they did not know how to write a certain word and helped each other edit the final work. Some of the more competent writers even played the role of scribes for the less capable.

Vygotsky's sociocultural perspective is fundamental from the practical point of view in teaching second and foreign languages, especially when we attempt to highlight the importance 
of creating an interactive environment in the writing classroom. His ideas have become well known and are used in the field of composition. Teachers of writing in L1 and L2 are making practical use of the ZPD or internal speech concepts and of the assertion that the social communication of a learner precedes and paves the way for the integration and development of both oral and written skills.

\section{THE CLASSROOM OF L2 AS AN AMBIT FOR THE ORAL CONCEPTION OF WRITING}

In addition to the regulatory function and the cognitive development that involves the oral participation in the processes of written composition, if this method of work is applied to teaching foreign languages, a didactic advantage aimed at addressing lexical, grammatical or cultural competency deficiencies in the goal language is added. In this respect, a recent work of Weissberg (2006) examines the ways in which the oral and written languages interact for learners of a second and a foreign language and describes a general approach to teaching which is deeply rooted in the dialogue in a triple tiered plane:

a) Dialogue between students and teacher;

b) Dialogue between students; and

c) Dialogue within the minds of the students.

His claim is based on the premise that, although writing is an activity often done by students working in isolation, it is a social attribute that can be acquired by learners of the second language when surrounded by dialogue. Although writing is a solitary activity, Weissberg (2006) maintains that teachers have the option of creating in their classrooms a community of writers that, through the dialogue, help one another as tutors, co-authors and critical readers. In line with this proposal, Corpas and Madrid (2007) recommend the use of cooperative composition techniques in the classroom. The techniques utilize working in pairs and in groups as a means of planning the possible organization of the texts by brainstorming, debates and discussions, interviews, etc.

The social context that Weissberg concentrates on is the writing class (although it is not the only one that he considers). He maintains that the foundation of an approach based on the dialogue about the teaching of writing in L2 is reflected in four assumptions:

1) The most effective language classrooms are those that are truly communicative, significant and relevant for pupils. Although this pronouncement is connected with the communicative approach to teaching oral language, it is also valid when applied to the acquisition of writing skills. Weissberg states that a noteworthy speech involves at least two active speakers with an important topic to discuss. Similarly, the communicative approach in writing involves interaction and a cooperative relationship between the writer and reader. This is achieved by being conscious of the readers to whom the writing is directed; good writers are capable of producing pieces that anticipate the information needs, as well as some possible reactions, of their target audience. Therefore, a manifest benefit of incorporating dialogue in writing classrooms is to help the writers in L2 to develop a strong sense of audience.

2) The use of communicative language involves people working together to exchange information, negotiate meanings and carry out tasks. This second affirmation refers to the organization of oral language classes in pairs and in small groups. Activities in small groups provide participants with the opportunity to negotiate meaning through conversation. In the 
writing class, brainstorming, group reviews and the personal tutorship help writers to generate and clarify their ideas and to apply a critical look at their own work. The pupils' dialogue with teachers and peers allows them to identify gaps in their logic, ambiguous references and contradictory affirmations in their writing, as well as possible solutions and suggestions to correct them. Hence, the second benefit of the creation of an environment of dialogue in the classroom is the provision of strategies to invent and review the content of the ideas presented and to develop coherence in writing.

3) Language learning in the classroom is, by nature, a social activity, thus interaction is not a precursor or a condition for learning the language but in itself a form of learning. The affirmation that learning a language in the classroom is inherently social, implies that to promote dialogue in the writing class is much more than just to give life to the lesson. This implies that the dialogue is in itself a general approach for teaching and learning a second language. For that reason, a perspective based on the dialogue can align all decisions involved in the process of instruction, from the way in which we introduce new written genres to the way of correcting the students' work. In this fashion, the dialogic approach gives us a consistent base to plan and execute writing lessons and to interact with the writers of L2 and their work.

4) Social interaction provides an ideal context to achieve dominion over complex cognitive skills such as writing. This last affirmation incorporates the notion that social communication is the basis for the development of literacy skills. This is the theoretical foundation that underlies Weissberg's position, which is based on Britton (1970) and Rubin (1988). The latter says (1988: 3): «As we internalize the discourse, it becomes thought. As we elaborate it by speaking, it becomes a bridge to literacy».

According to Weissberg (2006), these four affirmations, considered as a group, suggest that the incorporation of interaction in the classroom of writing is a logical and natural extension of the communicative teaching of language.

\section{Some Conclusions}

The interconnection of the common characteristics of speech and writing leads us towards a concept of an interactive classroom that helps resolve the processes of writing in a profitable manner. To seek ways of integrating linguistic skills in terms of a productive pedagogy emerges as a beneficial goal with direct implications for teachers, students and all other elements of the classroom.

The teacher remains a central figure in the process of instruction, not only as a reader of the work of the students but as a guide to the process of writing in the classroom. Therefore, the more teachers know about the written discourse (the factors that shape it, the message that the written text conveys in a given context, that the form and the content must fulfil a set expectations) the higher the probability that they could design sequences of instruction that will help students write effectively within a varied array of situations. It is true that we know very little about the role of such knowledge in the instruction, nevertheless, we can assist teachers to adopt the idea that writing is a dialogic process supported by an interactive atmosphere in the classroom.

Investigations conducted on the subject of the mother tongue indicate that the spoken language constitutes an indisputable base for the teaching of writing (Sanahan, 2006), as the 
spoken language as well as the written language use similar skills, such as working memory, cohesion and morphology, to mention a few.

The sociocultural perspective, strongly espoused by Vygotsky, has constituted itself as a manifest method of dealing with the writing class, particularly with regard to the incorporation of the dialogue as a didactic tool that encourages the formulation of questions ( to ask). The work in pairs stimulates the zone of proximal development enforcing even more strongly the concept of an interactive class for writing. To all this we must add that the inner speech, as a basis for writing, stands as a voice that encourages the learner's writing and establishes itself as a fundamental element of the planning process (Lee and Smagorinsky, 2000).

Finally, four essential points show that interaction and dialogue are essential elements for the execution of writing lessons. There is no doubt of the fact that the solid theoretical foundation associated with the practical applicability of Weissberg's ideas set the bases of a communicative pedagogy in accordance with the new conceptions of the Common European Framework of Reference for Languages (CEFR).

\section{REFERENCES}

Bisexx, G. (1980): Gnys at wrk: a child learns to write and read. Cambridge (Massachusetts): Harvard University Press.

Britton, J. (1970). Language and learning. Harmondsworth: Penguin.

Carlisle, J. F. (1996). «An explanatory study of morphological errors in children's written stories». Reading and Writing: an interdisciplinary journal, 8: 61-72.

Corpas, M. D. and Madrid, D. (2007): «Desarrollo de la producción escrita en inglés al término de la Educación Secundaria Obligatoria española», in Porta Linguarum, 8: 169-191.

Cox, B.E.; Shanahan, T. and Sulzby, E. (1990). "Good and poor elementary readers, use of cohesion in writing», in Reading Research Quarterly, 25: 47-65.

Cumming, A. (2001). "Learning to write in second language: two decades of research», in International Journal of English Studies, vol. 1, No2: 1-23.

Green, L.; McCutchen, D.; Schwiebert, C.; Quilan, T.; Eva-Wood, A. and Juelis, J. (2003). «Morphological development in children's writing», in Journal of Educational Psychology, vol. $95,4: 752-761$.

Herrera, J. (2005): «La investigación del lenguaje escrito como proceso. Algunas consideraciones de interés para la práctica docente», in Porta Linguarum No 3: 7-19.

Lantolf, J. and Thorne, S. (2000). Sociocultural theory and second language learning. Oxford: Oxford University Press.

Lee, C. and Smagorinsky, P. (2000). Vygotskyan perspectives on literacy research: Constructing meaning through collaborative inquiry. Cambridge: Cambridge University Press.

Luria, A.R. and Yudovich, F.I. (1968). Speech and the development of mental processes in the child. London: Staples Press.

McLane, J. (1994). «Writing as a social process», in L. Moll (ed.), Vygotsky and education. Cambridge: Cambridge University Press.

McCutchen, D. (1996). «A capacity theory of writing: working memory in composition», in Educational Psychology Review, 8: 299-325.

Pappas, C. (1985). «The cohesive harmony and cohesive density of children's oral and written stories», in J.D. Benson and W. S. Greaves (eds.), Systemic perspectives on discourse (vol 2). Norwood: Ablex. 
Pavlenko, A. and Lantolf, J. P. (2000). «Second Language learning as participation and the (re) construction of selves», in Sociocultural Theory and Second Language Writing. Oxford: Oxford University Press.

Prior P. (2001). «Voices in text, mind and society: sociohistoric account of discourse acquisition and use», in Journal of Second Language Writing, 10: 55-81.

Romero, A; Fdez. de Haro, E. and Núñez, M. ${ }^{a}$ P. (2008). Habilidades metalingüísticas y enseñanza-aprendizaje de la composición escrita. Granada: Grupo Editorial Universitario

Rubin, D. (1988). «Ways of talking about talking and learning», in S. Hynds and D. Rubin (eds.), Perspectives on talk and learning. Illinois: Urbana.

Shanahan, T. (2006). «Relations among oral language, reading and writing development», in C. MacArthur; S. Graham; J. Fitzgerald (eds.). Handbook of writing research. New York: The Guilford Press.

Sterling, M. (1996). «Revisiting the writing-speaking connection: challenges for research on writing and writing instruction», in Review of Educational Research, Vol. 66, No. 1, 5386.

Swain, M. and Lapkin, S. (1998). «Interaction and second language learning: two adolescent French immersion students working together», in Modern Language Journal, 82: 320337.

Vygotsky, L. (1978). Mind in society: the development of higher psychological processes. Cambridge (Massachusetts): Harvard University Press.

Vygotsky, L. (1996[1934]). Pensamiento y lenguaje. Barcelona: Paidós.

Weissberg, R. (2005). «Talking about writing: cross-modality research and second language speaking/writing connections», in P. Matsuda and T. Silva (eds.), Second language writing: perspectives on the process of knowledge construction. New Jersey: Lawrence Erlbaum.

Weissberg, R. (2000). «Developmental relationships in the acquisition of English syntax: writing and speech», in Learning and instruction, 10: 37-53.

Weissberg, R. (2006). Connecting speaking and writing in second language writing instruction. Ann Arbor: The University of Michigan Press.

Woodall, B. (2002). «Language switching: using the L1 while writing in an L2», in Journal of Second Language Writing, 11: 7-28. 